\title{
Detection of fraudulent actions in the financial statements with particular emphasis on hotel companies
}

\author{
Dragan Vasilev ${ }^{1}$, Dragan Cvetković ${ }^{2 *}$, Aleksandar Grgur ${ }^{3}$ \\ ${ }^{1}$ Service for Combating Organized Crime, SPBOK, Serbia \\ ${ }^{2}$ Police Directorate for the City of Belgrade, Criminal Police Directorate Belgrade, Serbia \\ ${ }^{3}$ ATOK, Belgrade, Serbia
}

\begin{abstract}
Financial statements are one of the key sources of information for stakeholders of companies. Therefore, financial reporting aims at presenting an objective and transparent state of an enterprise. In order to protect the interests of all stakeholders of companies, whether external or internal, the role of financial accountants is very important, which is related to the detection of fraudulent activities in the financial statements. Forensic accountants with the knowledge they possess in the field of accounting, auditing, management and other skills, have the ability to clearly understand the irregularities and injustices that occur within the company. Fraudulent actions are most often a case of using an enterprise management strategy to gain benefits to the interests of other marketers that surround it. The aim of the paper is to show the significance of the role of a financial accountant in detecting fraudulent actions in the financial statements. The subject of this paper is to investigate the possibility of fraudulent actions and to look into the specific role forensic accountants have in this process.
\end{abstract}

Keywords: financial statements, fraudulent actions, forensic accountants, forensic accountants tools, hotel companies

JEL classification: M40

\section{Otkrivanje prevarnih radnji u finansijskim izveštajima sa posebnim osvrtom na hotelijerska preduzeća}

Sažetak: Finansijsko izveštavanje ima za cilj prikazivanje objektivnog i transparentnog stanja preduzeća. Kako bi se zaštitili interesi svih interesnih grupa preduzeća, bilo eksternih, bilo internih, veoma je važna uloga forenzičkih računovođa, čija se uloga vezuje za otkrivanje prevarnih radnji u finansijskim izveštajima. Forenzičke računovođe uz pomoć znanja koje poseduju iz oblasti računovodstva, revizije, upravljanja i drugih veština, imaju mogućnost jasnog uvida u nepravilnosti i nepravednosti koje se javljaju unutar privrednog društva. Prevarne radnje su najčešće slučaj korišćenja strategije menadžmenta preduzeća radi sticanja koristi na uštrb interesa drugih tržišnih subjekata koji ga okružuju. Cilj rada predstavlja prikazivanje značajnosti uloge forenzičkog računovođe u otkrivanju prevarnih radnji u finansijskim izveštajima. Predmet rada je istraživanje mogućnosti nastanka

*cvetkovicdragan@mts.rs 
prevarnih radnji, te sagledavanje posebne uloge koju forenzičke računovođe imaju u tom procesu.

Ključne reči: finansijski izveštaji, prevarne radnje, forenzičke računovođe, alati forenzičkih računovođa, hotelijerska preduzeća

JEL klasifikacija: M40

\section{Introduction}

Financial statements are one of the most important results of the accounting function of the company, which makes them an important and indispensable source of information. The basic financial statements are balance sheet, income statement, cash flow statement, statement of changes in equity and notes to the financial statements (Zakon o računovodstvu Republike Srbije, 2013). However, no financial statement can provide a complete picture of the company, if it is viewed and analyzed separately from other statements. „The purpose of accounting is to record, and communicate to interested users, the effect of economic events or transactions on an entity" (Ross, 2016). On the other hand, financial statements can be used to obtain unlawful benefits from certain individuals in the company. In a situation where the information in the financial statements is presented untrue and does not present an objective financial position, then the published financial statements certainly do not fulfil the mission they are generated for. Fraudulent actions in financial statements play a major role in publishing transparent and sound financial statements. The scientific discipline concerned with the detection of fraud in the financial statements is forensic accounting. Forensic accountants use different methods and techniques to succeed in identifying and evaluating fraudulent actions that are the result of inadequate financial reports.

\section{The significance of financial reporting for stakeholders}

The financial statements represent the information basis for making decisions about investment, credit and other economic matters. Internal and external users expect the presented financial information to be understandable, reliable, relevant and comparable and should show the real state of the company in a certain period of time (Ross, 2016). Financial reporting is important for all interest groups - stakeholders. Stakeholders can be divided into internal and external.

Internal stakeholders are the owners and management of the company. External stakeholders are buyers, suppliers, creditors and the state. The owners of the company are interested in the indicators of the growth of the company, while the management is more focused on the current indicators, i.e. liquidity, solvency, profitability, etc. The indicators that are important for the management of the company are in the balance sheet and the income statement. The management of the company should be interested in all aspects of managing the company (Knežević et al., 2016). The owners of the company are interested in returning their own capital, the movement of own capital, indicators of activities and the like. In companies, there is often a conflict between the owner and the management of the company. The role of the company management is to increase the welfare of the company owners, without departing from the increase in the value of the company as a whole.

External users are all stakeholders surrounding the company. They apply to all users who have business activities with the company, that is, customers, suppliers, creditors, investors and regulatory authorities. Customers are most interested in activity indicators, which can be obtained from the income statement, while suppliers and creditors are most interested in liquidity and solvency indicators, i.e. balance sheet data. Activity indicators are very 
important for buyers because they use the inventories of the company, which can indicate its efficiency. High inventory turnover will result in higher customer satisfaction. Low inventory turnover may lead the company into a problem because it can be due to lack of sales, inventory obsolescence, saturation of demand, inadequate products and the like (Higgins, 2009). No customer will be interested in purchasing products or goods that have been in stock for a long time. Suppliers and creditors are interested in the liquidity of the company, or its ability to settle the due obligations within the deadline. It is very important for the company to have good business relations with these two groups of stakeholders because they should provide a smooth functioning of the company business activities. For this reason, financial reporting is very important because it represents an important relationship between companies and customers. The relationship between creditors, suppliers and customers can be shown through the indicators of the business activity of the company. If the company has a fast turnover of inventories, it is more likely that it will be liquid, which is also a stable basis for an efficient financial policy. On the other hand, investors are most interested in the profitability and market value of shares of the company. Profitability indicators show the degree of return on shareholders' equity, that is, they are one of the main indicators of the market value of shares. From this point of view, the company should find the optimal ratio of reinvested earnings and dividend payments in order to maximize the market value of the share. A large amount in the name of the dividend will attract dividendoriented shareholders, but this can not be a long-term solution, because high dividend payments, and small amounts of reinvested earnings, indicate a small possibility of company growth, and consequently a decrease in market value of the shares. A high amount of reinvested earnings will increase the growth ability of the market value of shares, but on the other hand, it will dissuade dividend-oriented investors. In addition to profitability, investors must pay attention to cash flows that are often the subject of manipulative actions in the financial statements (Knežević et al., 2011).

The state and regulatory bodies represent a stakeholder group whose main focus is on the liquidity and growth indicators of the company. Regulatory bodies should provide a framework for timely information on the illiquidity of certain companies, so that a contracting party would not be damaged, as well as for the transparency of reporting by all companies. The state is interested in determining short-term liquidity, for the purpose of certainty of payment of taxes, fluctuation of employees and the volume of production and sales of a company. Regular fulfilment of tax obligations is of particular importance for the management of public revenues so that the stated tax obligations (corporate tax) should be presented on a realistic basis.

\section{Fraudulent financial reporting in hotel companies}

The International Standard of Auditing (ISA) 240 (IAASB, 2016) defines corporate fraud as "an intentional act by one or more individuals among management, 2 those charged with governance, employees or third parties, involving the use of deception to obtain an unjust or illegal advantage" (Dorris, 2018).Financial statement fraud is thus fraud committed by the management of an organisation with the goal to artificially improve the financial performance and results of the company as stated in the financial statements. False financial reporting is a criminal act that deceives users of financial statements in order to make future decisions in favor of the legal entity that created the financial report and to the detriment of users of information from the financial statements (Coenen, 2008). No one can know how many failures in the business of the company are actually caused by fraudulent actions, but a large number of small and medium-sized enterprises are bankrupt, precisely because of the losses that result from fraudulent activities in financial reporting. Falsifying of financial statements primarily involves manipulating elements by 
overstating assets, sales and profits, or understating liabilities, expenditures or losses. Fraudulent financial statements are the product of manipulation management, especially the executive and finance director, because without their participation it would not be possible to prepare and make a financial report ( $\mathrm{Md}$ Shamimul et al., 2017). The most common forms of fraudulent actions in financial statements are (Reilly \& Swisher, 2015):

- "fictitious revenue recognition;

- $\quad$ hiding obligations;

- non-disclosure of transactions with related legal entities;

- improper asset valuation."

One of the most common cases when doing fraudulent actions in hotels is fictitious revenue recognition. The hotel industry is capital intensive, which is why it faces high fixed costs, which not all hotels can cover. The way to increase company income, and therefore the performance of the company is done through fictitious revenue recognition (Dorris, 2018). Fictitious revenue implies the absence of real customers. Fictitious bills based on goods and services turnover are made, their booking is done without any inflow of funds into the account of clients. In this way, revenue increases, resulting in an increase in profits that have not got coverage in cash flows. The financial statements also disclose claims for which it is known in advance that they are uncollectible and will be written off in some future period (Ministarstvo finansija Republike Srbije, 2013). When there is revenue at the moment of delivery of goods or services, regardless of whether the product or service fee is paid, such a situation creates room for manipulation. Namely, the hotel may record revenue on behalf of the delivered service, although it knows that it will not obtain the money, but it will become customer receivables, which will later be written off.

Liabilities and costs are hidden in order to show a better financial position of the company. With the exclusion of obligations and costs, the company may try to hide loan agreements or other debt from stockholders with the intention of presenting a better position of the company (Riley \& Razaee, 2008). The common situation that happens with the hotel to disguise the obligations that the hotel has towards the owners of the company, or noncompany creditors, with which the hotel hides these loan agreements, in order not to come into the situation of being marked as indebted. The situation in which the company's liabilities are hidden is especially present at hotels with high debt and capital ratios.

Non-disclosure of transactions with legal licenses relates to situations where hotels may ignore invoices of the seller, and do not take them into account when preparing financial statements. As invoices are one of the main procurement control documents (Martin, 2004), they must, as a rule, be kept in the hotel and at the seller. Non-reporting of invoiced transactions may be reflected in legal implications in the following year. If the hotel does not record the invoice it receives from the buyer, it risks being legally convicted. The goal of the hotel is to reduce the amount of the company's costs and overestimate the profit when not reporting the invoices. Hotels in this way manipulate the profit by displaying better performances and thereby gaining a better relationship with the lenders and hotel owners. A frequent case of non-disclosure of transactions in the tourism industry is among the hotels and travel agencies. Namely, there may be a situation in the organizational structure of the hotel and tourist agencies that have persons that are related in private life. In this way, there is a possibility of non-disclosure of transactions, which will not be reflected later in the financial report, although it is executed.

An incorrect valuation of assets relates to overvaluation or underestimation of the value of the property of a hotel intended to be sold, in order to benefit at the expense of the interests of users of information from the financial statements. When selling a particular fixed asset, 
hotel managers can overestimate the value of assets to generate higher profits from the sale of a fixed asset, and thus show better performance of the company. The benefit of the hotel, in this case, will relate to a better financial position, which is set on a false basis. On the other hand, if the hotel intends to reduce its tax base, it will, together with the evaluator, conclude the contract, reducing the value of the asset, and consequently the incomes from the sale of assets in order to avoid payment of taxes. In this situation, there may be another form of fraud, where the contracting between the hotel and the appraiser determines the underestimated value of the asset for reporting purposes, and the remaining difference between the real value of the asset and the subtraction of value is shared between the assessor and the authorized hotel manager.

The practice so far has pointed to the existence of numerous and varied ways of committing fraudulent activities in the hotel business, which certainly have a negative impact on the quality of the financial information presented in the financial statements and thus on the amount of the taxable base and the quality of the services provided to customers. Below, some of them are presented:

- Individuals are engaged in hotel/catering business even though they are not registered for this. Goods are purchased on a black market for cash, after which they are sold at catering establishments at much higher prices than purchasing, while providing catering services for cash, without showing them in the financial statements and without paying the corresponding taxes to the state.

- In order to reduce the amount of the tax base, some hotels/restaurants, show in the bookkeeping documents that the goods were purchased/bought at much lower prices than the selling price, mainly at a price which is only 1-5\% lower than the selling price. In this way, they minimize their taxable income.

- Some people who are engaged in the sale of food and beverages sell food and beverages from the kitchen or bar without registering their sales to the appropriate sales account and using them for their own needs or selling to the guest of the hotel/restaurant taking the received money from the user without giving a sales account and recording the sale.

- Some hotels/catering facilities can be fraudulent in three directions with one sale: quantity, quality and price of sold goods/services to hotel/restaurant guests. This form of fraud is one of the most massive. The essence is that the goods are sold above the price determined by the management. Particularly favorable for it is the market demand for these hotels, restaurants (for example, due to a good location, etc.), as well as the negligence of guests regarding quantity, quality and price. Workers save on the amount of beverage they pour, and in that way, they still have enough quantity for additional drinks that they will sell without registration; procure drinks on their own and sell it without any records; dilute drinks and take money from extra sales, charge high-quality goods (beverages) and deliver low-quality goods (for example, they replace a good quality wine with a lower quality one, and charge it as a better quality wine. They retain the difference in price to themselves.

- Some employees at the reception delete from the guest book the guest who came late and left early and made a payment and take his money; constitute false charges/payments that were allegedly immediate or that they could not "wait".

- Issuing invoices to the guests of the hotel without the number of the same.

The users of the financial statements are concerned about the correctness and truthfulness of the financial statements. When the financial statement contains counterfeit amounts, so that the elements do not reflect the true picture, then we are 
talking about fraud. Such financial statements do not help business decision makers, but instead, by presenting incorrect data, they mislead decisions that result in the inefficient allocation and use of resources. Managerial fraud can be defined as "deliberate fraud by the management of the company, thereby distorting the interests of investors and creditors through misrepresented financial statements". Management by making false financial statements use strategies to show more or less profit in relation to the achieved one, in order to gain a certain benefit, at the expense of the interests of certain stakeholders. Like company management, auditors may have a personal interest in achieving personal material benefits due to the non-disclosure of fraud in the financial statements.

\section{The role of forensic accountants in detecting fraudulent actions}

The decision on engaging forensic accountants can be made by the management of the company, the owner but also the other users of the financial statements, if they need an objective, independent and expert assessment of whether there are criminal acts in the company and, therefore, whether the data in the financial statements are true, relevant and reliable. Engagement of forensic accountants aims at:

1. Detecting areas of possible irregularities, or narrowing the error field;

2. Detecting specific irregularities;

3. Assessment of the level of risk of identified irregularities (deliberate or unintentional, high or low level of irregularities, etc.);

4. Presentation of evidence (for court proceedings).

"Forensic accountants with the knowledge they possess in the fields of accounting, auditing, management and research skills, have the ability to clearly understand (ir) regularities and (un)fairness that occur within a company"(Koletnik \& Kolar, 2008). In criminal activities in organizations, the goal is to determine whether the criminal act has already happened or happens and determine who its perpetrator is. In support of disputes, the client is the one who determines the goal.

During the investigation, forensic accountants are not limited to the internal area (employees and managers), but also take into account the external area, or the possibility of criminal actions by business partners (customers, suppliers, banks and/or other partners). Like every serious job, an investigation conducted by forensic accountants requires a certain kind of preparation. Namely, before starting the investigation, the investigators must master the rules of financial accounting; to study in detail the International Financial Reporting Standards; master the skills of analyzing financial reports; examine the accounting techniques that most often appear in the formulation of financial statements; master the rules, techniques, and skills of analyzing criminal actions.

The procedure for performing forensic accountant tasks takes place in the following steps (Muminović, 2011):

1. The start of the investigation (engagement of a forensic accountant, defining the objectives of the investigation);

2. Theoretical analysis of criminal acts;

3. Forming a plan of evidence collection;

4. Collection of evidence;

5. Analysis of the collected evidence;

6. Producing a report on the findings of the forensic accountant. 
The first step in the investigation of a criminal act is the initiation of an investigation. If we are talking about criminal activities in the organization, then this usually starts with a warning or accidental discovery of a criminal act reasonable doubt is necessary in order to investigate criminal activities. The reasonable doubt is a set of circumstances that, in a prudent and reasonable manner, indicate a professionally trained individual to believe that a criminal act has already happened, is happening or will happen. However, in support of disputes, the suspicion is made by the legal representative.

In a situation where the criminal act is not known or the existence of limited information about this criminal act, the next step would be the theoretical approach to the criminal act. Based on this approach, a forensic accountant using "brainstorming" ${ }^{1}$ suggests a more likely criminal scheme and the possible way in which such a criminal scheme could be committed in a damaged organization. It is clear that the forensic accountant must know the methods of criminal actions and warning signs for each of these criminal schemes. Theoretical knowledge then serves as the basis for the elaboration of an investigation plan, i.e. the plan of a collection of evidence. Using this theory, a forensic accountant develops a plan for collecting sufficient and relevant evidence. This is a step in which a crime auditor comes to a special expression. Under this step, an examination of accounting records, transactions, documents and data is carried out in order to obtain sufficient evidence to confirm or challenge the previously identified criminal act (Singleton \& Singleton, 2010).

After collecting accounting evidence forensic accountants are trying to collect evidence from eyewitnesses through interviews. This process is based on people who are the furthest from the criminal act (they are not involved in such actions, but can possess certain knowledge) to narrowing down of the circle of people who were in the immediate vicinity of the criminal act (first-hand knowledge) until the last step, which is to conduct interviews with suspects.

It is important to note that the last step in the investigation process is to approach the suspect. This can happen with intent or by accident. An intentional approach is easy to avoid but random access requires additional efforts. When an investigator encounters an anomaly (a document, an accounting transaction, or other evidence of something that should not be there or as a warning sign that relates to criminal actions or a violation of internal controls) before accessing a particular person for the purpose of obtaining an explanation, the investigator should first determine whether the cause of such anomaly is a possible criminal act or not. The reason for this prudence is the case when unconsciously we have the proof in our hands and when we turn to the side responsible for the criminal act and ask that person to give explanations in the disclosure of the discovered anomaly. At this point, the research is, at best, significantly hampered and, in the worst case, already compromised (Singleton \& Singleton, 2010).

Upon completion of the investigation, a forensic accountant expounds his findings in a report whose form and content dependon the purposes it has been compiled for. As the results of an investigation, a report may be drawn up for the contracting authority under the name of an investigation report or a report for the purposes of judicial proceedings when designated as an expert report. Regardless of the form of a report, the forensic accountant must be objective and professional when compiling it. This means that, regardless of whether the case will come to court, the work of a forensic accountant has to be effectively demonstrated. The report purpose is to present the investigation results in a way that would allow the users of the report to make the correct decision. The information contained in the report must be accurate, clear, impartial, relevant and timely.

\footnotetext{
1 Webster's (Merriam-Webster) dictionary defines brainstorming as a "group-solving technique that involves spontaneously getting ideas by all members of the group in order to solve the problem," but also as "designing ideas by one or more individuals with the aim of solving a particular problem."
} 
The report must contain information to assist the investigation of the competent state authorities, to be sustainable in court, but not explicitly to accuse an individual of a group of employees. For this reason, forensic accountants have to be very careful in forming the reports, especially regarding the manner of expression in connection with the investigation. Therefore, after performing these steps, there are two possibilities. One is that the perpetrator of a criminal act has been identified and that there is sufficient evidence to substantiate the underlying suspicion of his criminal responsibility, wheras the other is just the opposite. If the perpetrator is not known, further research needs to be carried out. Otherwise, the evidence collected during the investigation may include witness statements, collected documentation, means of executing a criminal act, assets as a result of the criminal act committed and, possibly, recognition of the perpetrator. Experienced investigators know what evidence is essential and necessary to prove certain crimes and how to obtain such evidence. An interview with the suspect or the taking of a statement is done only after all relevant data has been identified, collected, assessed and explained.

\section{The tools used by a forensic accountant}

In the phases of carrying out the task, a forensic accountant applies different analytical procedures or techniques to identify areas of criminal activity. In their work, among other things, the financial accountant uses analytical techniques for analyzing the relationship between items in the financial statements, or analysis of business transactions. From the procedures in modern accounting and financial practice, investigators use the following analytical procedures:

- horizontal analysis;

- vertical analysis;

- ratio analysis;

- mathematical methods and models.

These are the techniques that break down the problem to the detail in the context of forming a comparison of certain interconnected segments of the business, and these relationships eventually, possibly, imply the possibility of a criminal act. They represent a useful tool in determining whether individual accounts balances, balance positions, have a greater chance of being the subject of criminal actions (AICPA-CPA Letter Supplements).

Due to the fact that in the bookkeeping, every recorded business event is reflected in two or more accounts of financial statements, it is reasonable to expect that there are firm correlations between the data that are contained and disclosed in those reports (for example, accounts receivable by nature of things always have a correlation with sales revenue accounts). It is precisely on these premises that an analysis of the financial statements is based, which essentially represents an analysis of significant indicators and trends, including test results, fluctuations and relationships that are not consistent with other important information or deviating from pre-set sizes (Andrić et al., 2008). Based on the stated guidelines, it can be clearly concluded that the basic characteristic of analytical procedures is that they bring their results and conclusions based on the comparison of certain data from which in practice the most commonly used are the following (Golden et al., 2006):

- Comparison of the company's current data in relation to data from previous periods;

- Comparison of the data of the company with regard to the data expressed in the budgets, forecasts or projections;

- Comparisons of data from companies in relation to business branch data and/or comparable data from other market participants; 
- Comparison of the financial data of the company in relation to its non-financial (operating) data;

- Comparison of the data of the company in relation to the previously determined and expected data.

As with any other analysis of financial statements, the horizontal and vertical analysis does not in any way incriminate anyone or proves the existence of criminal activities, but only represents an indication of the possibility of having financial irregularities in one or more areas of business. It is necessary to point out several mathematical methods and models that can be used to support the analysis of financial statements aimed at detecting illegal financial procedures, as well as predicting bankruptcy that may result from financial fraud. Among the most commonly used are Altman's Z, Benford's law and Beneish M-score.

Also, one of the ways of detecting criminal actions in financial statements is the use of appropriate computer software, which is able to track and record certain discrepancies in bookkeeping, employee procedures, using inadequate documentation, and the like. The unusual activities are recorded and reported by the software to the competent controllers. Analyzing data in the accounting system, the software can spot certain signals of possible fraud, among which the most important are:similar names of buyers or suppliers, whereby the fraudster attempts to "push through" false invoices using non-existent customers or suppliers; similar customer or supplier information; the same address of the buyer or supplier and the address of any of the employees; payment to the buyer or supplier made to a current account or address that does not correspond to their basic data, payment in identical or similar amounts, frequency of repayment of payments made to customers or suppliers by the employees.

\section{Conclusion}

Detecting fraudulent acts, for its own sake, aims at protecting the interests of all interest groups in a company. Fraudulent actions, like all other illegal activities, must be legally sanctioned, and the perpetrators adequately punished. Most professional fraudulent actions show certain behaviors that may be warning signs of their crimes.

Management, employees, auditors and others should be trained in identifying warning signs, which in combination with other factors could indicate a fraudulent act. Detection and evaluation of fraudulent actions require the role of financial accountants, who must be trained to combine various methods and techniques, discover and report on time to the competent authority on fraudulent activities in a company. The detected fraudulent act does not always have to lead to the perpetrator of a criminal act. Namely, if the perpetrator is not known, further investigation is needed in order to reach the perpetrator and sanction him or her. Acquiring the unlawful benefits of certain entities in an enterprise is not ethical and moral, and on the other hand, it is almost in all cases reduced to the violation of the interests of certain stakeholders. Modern forensic accounting requires, in addition to traditional financial analysis, the application of certain information and communication technologies in detecting fraudulent activities. In today's environment, the detection of fraudulent activities should become a continuous process, in order to recognize a certain violation of regulations in time, and thus achieving great savings in company costs, which can consequently lead to the bankruptcy of the company. 


\section{References}

1. AICPA-CPA Letter Supplements, M. 1. (n.d.). Retrieved January 11, 2019 from www.aicpa.org/pubs/cpaltr/may98/suppl/pubacc.html

2. Andrić, M., Krsmanović, B., \& Jakšić, D. (2008). Revizija - Teorija i praksa [Auditing Theory and Practice]. Subotica: Ekonomski fakultet.

3. Coenen, T. (2008). Essentials of Corporate Fraud. New York: John Wiley \& Sons, Inc.

4. Dorris, B. (2018). Report to the nations, 2018 Global study on occupational fraud and abuse. New York, Association of Certified Fraud Examiners.

5. Golden, W. T., Skalak, L. S., \& Clayton, M. M. (2006). A Guide to Forensic Accounting Investigation. New York: John Wiley \& Sons.

6. Higgins, R. C. (2009). Analysis for Financial Management 9th Edition. New York: McGraw-Hill.

7. IAASB, I. A. (2016). Handbook od international quality control, auditing, review, other assurance and related services pronouncements. New York.

8. Knežević, S., Barjaktarević-Rakočević, S., \& Đurić, D. (2011). Implementation and Restraints of Ratio Analysis of Financial Reports in Financial Decision Making. Management, 61, 24-31.

9. Knežević, S., Mitrović, A., \& Ilić, Z. (2016). Pogledi na izveštavanje o tokovima gotovine iz različitih perspektiva [Different perspectives on the cash flow statement]. Menadžment u hotelijerstvu i turizmu - Hotel and Tourism Management, 4(2), 48-54.

10. Koletnik, F., \& Kolar, I. (2008). Forenzično računovodstvo [Forensic accounting]. Udruženje računovođa, forenzičara $i$ revizora Slovenije, Ljubljana [Slovenian association of accountants, forensics and auditors].

11. Martin, G. J. (2004). Hospitality management accounting. 8th edition. New Jersey: John Wiley \& Sons.

12. Md Shamimul, H., Normah, O., Barnes, P., \& Morrison, H.-S. (2017). A cross-country study on manipulations in financial statements of listed companies: Evidence from Asia. Journal of Financial Crime, 24(4), 656-677. https://doi.org/10.1108/JFC-07-2016-0047

13. Ministarstvo finansija Republike Srbije. (2013). Ministarstvo finansija Republike Srbije - Uprava za sprečavanje pranja novca [Ministry of Finance of the Republic of Serbia Administration for the prevention of money laundering]. Retrieved January 11, 2019 from

http://www.apml.gov.rs/REPOSITORY/977_tipologije-pranja-novca-u-republici-srbiji13-09-2011.pdf

14. Muminović, S. (2011). Forenzičko računovodstvo - potreba ili pomodarstvo [Forensic accounting - need or newfangled]. Revizor, 14(54), 18-19.

15. Reilly, K., \& Swisher, T. (2015). The Five letter F Word : Fraud in the Hospitality Industry. HFTP Annual Convention. Seattle Washington: PBMares.

16. Riley, R., \& Razaee, Z. (2008). Financial Statement Fraud: Prevention and Detection. 2nd Edition. New York: John Wiley \& Sons, Inc.

17. Ross, J. F. (2016). The Information Content of Accounting Reports: An Information Theory Perspective. Information, 7(3), 1-23. https://doi.org/10.3390/info7030048

18. Singleton, T., \& Singleton, A. (2010). Revizija kriminalne radnje $i$ forenzičko računovodstvo [Revision of criminal acitivity and forensic accouning]. Savez 
Računovođa i Revizora Srbije [Serbian association of accountants and auditors], Beograd.

19. Zakon o računovodstvu Republike Srbije. (2013). Sl.glasnik (62/2013) [Accounting Act, Official Gazette of RS no. 62/2013].

Received: 18 November 2018; Sent for revision: 28 January 2019; Accepted: 21 April 2019 